\title{
Modeling (Im) mobility: the decision to stay in disaster prone area amongs fishermen community in Semarang
}

\author{
Choirul Amin ${ }^{1, *}$, Sukamdi $^{1}$, and Rijanta ${ }^{1}$ \\ ${ }^{1}$ Geography Doctoral Program, Universitas Gadjah Mada, Indonesia
}

\begin{abstract}
The existing literature on population immobility, especially immobility associated with climate change-related disaster, is very finite. Consequently, the understanding of population immobility in disasterprone areas is still low. This article adds to the literature on population immobility by modeling decision to stay in the disaster-prone area amongst fishermen community in Tambak Lorok, Semarang. The survey was conducted among the residents of Kampung Tambak Lorok Semarang, which is prone to 3 disasters simultaneously i.e. sea level rise, land subsidence, and tidal inundation. The study sample was 235 heads of households selected using proportional sampling area technique. This study constructs three factors: place valuation, disaster adaptation, and stakeholder intervention. These three factors used as explanatory variables for modeling the decision to stay. The study employed a Confirmatory Factor Analysis using Partial Least Squares Structural Equation Modeling (PLS-SEM) to analyses the data and examines the logical relationship between those three factors in staying decision. Our results suggest that the place valuation and disaster adaptation significantly influence the decision to stay, while stakeholder interventions are influential but not significant. We concur that residents with positive place valuation and good disaster adaptation tend to stay although threatening by disaster. More broadly, this study contributes to our understanding of population immobility in the disaster-prone area by modeling the decision to stay.
\end{abstract}

\section{Introduction}

There are significant challenges emerging for the globe in relation to both future human mobility and the broader impacts of climate change. The interaction between these two processes is little understood and significantly under-researched [1].

As it is known that population migration divided into 2 forms: permanent migration and non-permanent migration (also called circular migration) [2,3]. But distinguishing migrations from being permanent and circular causes the concept of migration as a process are neglected. In addition to definitive categories such as permanent and circular, in the context of migration as a process, there is another category that exists between the two. This happens in cases where the decision to move has not yet existed, so there is a phase of migrants that cannot yet be classified as circular migrants or permanent migrants [4].

In explaining why people move (migrate), we have taken our eyes off the crucial counterfactual question: why do so many people not move [5]. Meanwhile, the perspective on migration has two sides like coins, namely mobility (moving) and immobility (not moving). One of the future challenges to build a stronger and more nuanced migration theory is the importance of explanation of people who do not migrate (immobile) [6]. Nevertheless, the study of population immobility, especially the immobility associated with climate change-related disasters, is still very rare. Thus the understanding about people who do not move from disaster-prone areas is still blurred.

From an individual perspective, migration is a rational response to the conditions of the place of origin by considering the push and pull factor [7]. However, in some cases, there are individuals who do not move when there is an adequate push and pull factor in their place of origin. One example is the case in Semarang city coastal area whose residents live in areas that experience sea level rise, land subsidence, and tidal inundation (rob) simultaneously.

The coast of Semarang is vulnerable to various environmental problems such as tidal inundation, land subsidence, and flood during the rainy season [8]. Most of the coastal areas of Semarang (20 urban villages) have high levels of risk, vulnerability, and a threat to tidal inundation [9]. The causes of tidal inundation are sea level rise due to climate change and land subsidence $[10,11]$. The impact of tidal inundation is estimated to be higher with the assumption of sea level rise and land subsidence which constantly increase to $15 \mathrm{~cm} /$ year [12]. Tidal inundation makes Semarang coastal area often flooded. The area becomes unsafe and uncomfortable.

People living on the coast of Semarang have been experiencing the threat of almost constant tidal inundation with various depths of inundation. Even the tidal water is gradually getting higher and it is far worse for residents. In terms of knowledge about the danger of tidal inundation, $93 \%$ of the research respondents are aware that the area where they live in is an area affected by tidal inundation [10]. Rationally, the people living in

\footnotetext{
* Corresponding author: ca122@ums.ac.id
} 
there should move to a safer and more comfortable place. However, they still remaining stay in the area.

The facts revealed reference 10 is interesting to examine in relation to disaster-induced migration. When viewed from the push-pull model in reference 7, residents who did not move from disaster-prone areas in the coastal area of Semarang had strong push factors to make them migrate. But in fact, they did not move (immobile) from there.

If the push-pull model cannot be used to explain the phenomena in the coast of Semarang, then the question lies in other factors, i.e. individual factors and intermediate barriers. Individual factors include the perception or valuation of an individual, both on the condition of the origin and destination of migration covering various aspects of economic, socio-cultural, political and environmental. This valuation depends heavily on the individual character, his experience, and his openness to information [13].

Therefore, our aim in this study is to investigate the relationship between place valuation, disaster adaptation, stakeholder intervention and staying decision. In a broad sense, this research will explain population immobility by modeling decision to stay in the disaster-prone area on the coast Semarang. The model developed in this study describes the logical relationship between several important factors in the decision to stay in disaster-prone areas. In order to understand the stay decision, this study developed a conceptual framework of decisions to stay that are influenced by variables of place valuation, disaster adaptation, and stakeholder intervention.

This research hypothesis is H1: Place Valuation is positively related to decisions to stay in disaster-prone areas, H2: Disaster Adaptation is positively related to decisions to stay in disaster-prone areas, and H3: Stakeholder Intervention is positively related to decisions to stay in disaster-prone areas.

\section{Research method}

This research used a survey research method. Surveys were conducted for people living in disaster-prone areas. The area chosen as the research location is Semarang coastal area that is most severely affected by tidal inundation. Kelurahan Tanjung Emas is one of the coastal areas in Semarang facing high risk, threat, and vulnerability to tidal inundation9. The areas in Kelurahan Tanjung Emas with the highest levels of risk, threat and vulnerability to rob flood are Kampung Tambak Lorok.

Kampung Tambak Lorok chose as the research location based on 3 considerations, namely: (1) the most severe areas affected by tidal inundation (has highest physical push factor); (2) the most populous area (has highest social push factor); and (3) the areas with the greatest number of poor people (has highest economic push factor). Kampung Tambak Lorok is part of Kelurahan Tanjung Emas, North Semarang Subdistrict, Semarang City, Central Java Province, Indonesia. The total area of this kampong is about $31 \mathrm{Ha}$ which is divided into 5 Rukun Warga (RW), i.e. RW XII, XIII, $\mathrm{XIV}, \mathrm{XV}$, and XVI. Tambak Lorok is the biggest fisherman community in Semarang located on the northernmost part of Kelurahan Tanjung Emas (as seen in Figure 1).

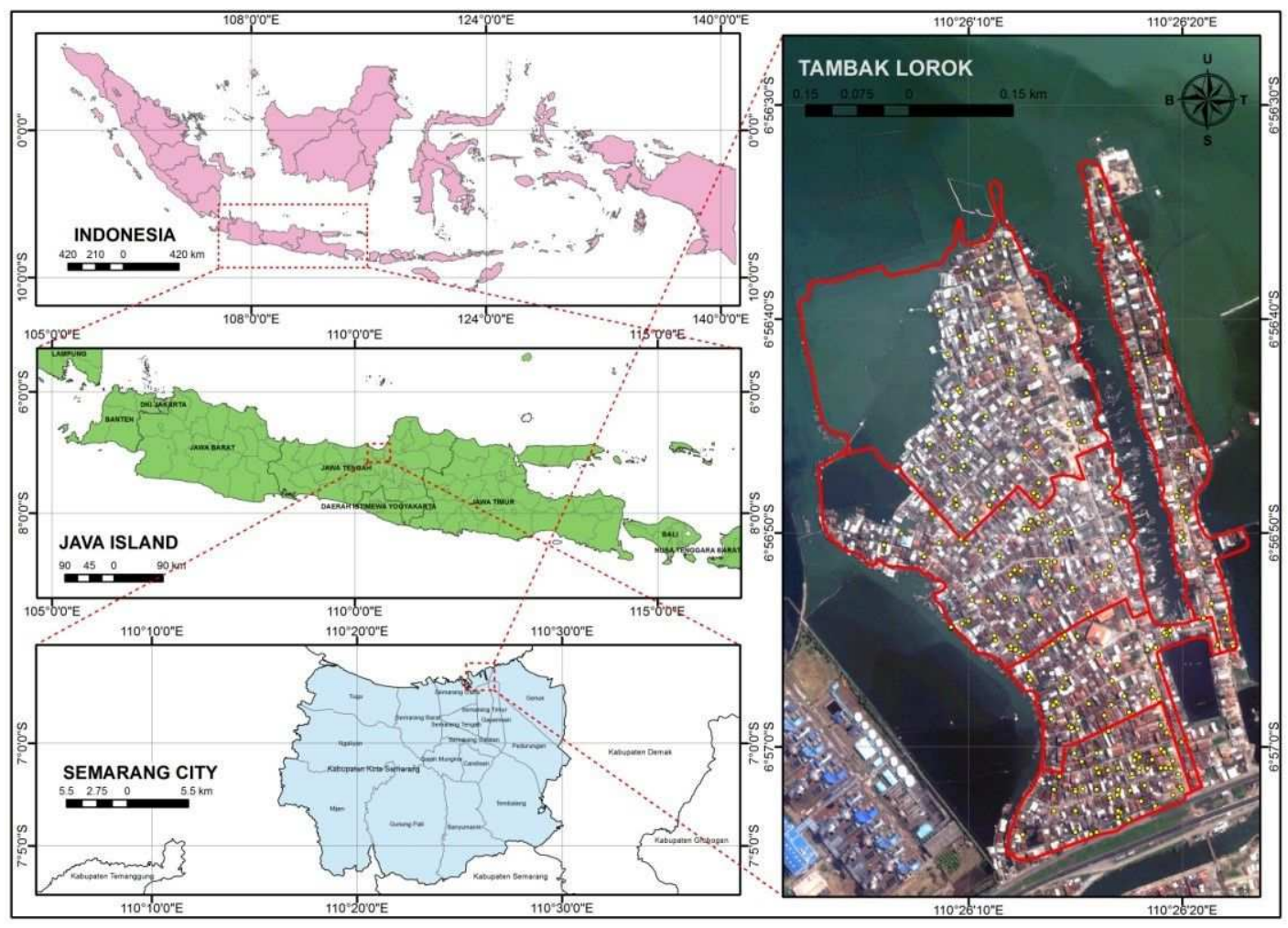

Fig. 1. Research location. 
Therefore, considering the high level of migration push factors, the people in the area should move to other regions because the economy is not promising, physically dangerous, and socially unfavorable. But in reality, residents in the area do not move elsewhere.

The research subjects were resident of Kampung Tambak Lorok which amounted to 1,468 heads of households (Monograph of Kelurahan Tanjung Emas, 2016). The sample size was 235 heads of households (calculated using Slovin formula [14] with $94 \%$ significance level). The sample selected using proportional area technique, where the sample selection based on the area of Rukun Warga (RW) in Kampung Tambak Lorok. Kampung Tambak Lorok consists of 4 RWs (i.e. RW XII, XIII, XIV, XV, and XVI) with the proportion of the sample in each RW is $16 \%$ of the total number of households in each RW (Table 1).

Table 1. The proportion of samples at each RW in Tambak Lorok.

\begin{tabular}{|l|c|c|}
\hline Area & $\begin{array}{c}\text { Number of heads } \\
\text { of households (N) }\end{array}$ & $\begin{array}{c}\text { Number of samples } \\
(\mathbf{1 6} \% \text { of N) }\end{array}$ \\
\hline RW XII & 337 & 54 \\
\hline RW XIII & 235 & 38 \\
\hline RW XIV & 363 & 58 \\
\hline RW XV & 368 & 59 \\
\hline RW XVI & 165 & 26 \\
\hline Total & 1468 & 235 \\
\hline
\end{tabular}

The data were collected using questionnaires that arranged according to the conceptual framework of research which further developed in the form of question items based on the purpose of this research. The decision to stay is a multidimensional latent variable and difficult to observe directly. Therefore, this study measures it indirectly with a set of measurable indicators (observed variable). Table 2 shows the variables in this study.

Data were analyzed using descriptive analysis and structural model analysis. Descriptive analysis is used to describe the characteristics of respondents and research variables, while structural model analysis is used to test the research hypothesis. Structural model analysis using SEM PLS. SEM PLS does not use the goodness of fit index criteria as in covariance-based SEM. The criteria used in SEM PLS comprise evaluation of the outer model and inner model. The software used in data analysis is SmartPLS Version 2.

The model analysis should consist of two-step approaches in order to obtain and interpret the results, i.e. testing the outer model and the inner model. Before assessing the inner model (structural model), it is important to ensure the validity of the model, the reliability of the construct and its indicators, and that theoretical concept is correctly measured through the observed variables [15]. The result of the analysis is the staying decision model (conceptual framework) in disaster-prone areas.
Table 2. Research Variables

\begin{tabular}{|c|c|c|}
\hline & $\begin{array}{c}\text { Latent/unobserved } \\
\text { variable }\end{array}$ & $\begin{array}{c}\text { Indicator/observed } \\
\text { variable }\end{array}$ \\
\hline \multirow{12}{*}{$\begin{array}{l}\text { Exogenous } \\
\text { variable }\end{array}$} & \multirow[t]{4}{*}{ Place valuation } & Physical Valuation \\
\hline & & Social Valuation \\
\hline & & Economic Valuation \\
\hline & & $\begin{array}{l}\text { Family Future } \\
\text { Valuation }\end{array}$ \\
\hline & \multirow[t]{4}{*}{ Disaster adaptation } & $\begin{array}{l}\text { Individual } \\
\text { Adaptation }\end{array}$ \\
\hline & & $\begin{array}{l}\text { Socio-Culture } \\
\text { Adaptation }\end{array}$ \\
\hline & & Physical Adaptation \\
\hline & & $\begin{array}{l}\text { Economic } \\
\text { Adaptation }\end{array}$ \\
\hline & \multirow[t]{4}{*}{$\begin{array}{l}\text { Stake holder } \\
\text { intervention }\end{array}$} & $\begin{array}{l}\text { Land Ownership } \\
\text { Certification (SHM) }\end{array}$ \\
\hline & & $\begin{array}{l}\text { Infrastructure } \\
\text { Development }\end{array}$ \\
\hline & & Cash Assistance \\
\hline & & $\begin{array}{l}\text { Banking Credit } \\
\text { Facility }\end{array}$ \\
\hline \multirow{4}{*}{$\begin{array}{l}\text { Endogenous } \\
\text { variable }\end{array}$} & \multirow{4}{*}{$\begin{array}{l}\text { Decision to } \\
\text { stay }\end{array}$} & Length of Stay \\
\hline & & Staying Intention \\
\hline & & Mobility Experience \\
\hline & & $\begin{array}{l}\text { Access to } \\
\text { Information }\end{array}$ \\
\hline
\end{tabular}

\section{Results and discussions}

\subsection{Results}

\subsubsection{Characteristics of residents living in disaster prone areas}

Characteristics of respondents i.e. residents who did not move from tidal inundation-affected areas in coastal Semarang described by age, place of birth, length of stay, education level, type of work, and income.

The age characteristics of respondents are mostly in the productive age between 24 to 63 years old $(90 \%)$, while those who are unproductive (aged over 64 years) are only a small part $(10 \%)$. While the place of birth respondent shows the area of origin. The respondents who are natives of Kampung Tambak Lorok (born in Tambak Lorok) were $43.4 \%$, while the respondents who were born outside Tambak Lorok were $56.6 \%$. This indicates that more than half of all respondents are immigrants from outside the research area. That is, they were born outside Kampung Tambak Lorok and then moved to Kampung Tambak Lorok.

Most of the respondents have been living in Tambak Lorok between $21-40$ years $(45.1 \%)$ and over 41 years (37\%). It means most respondents have been living in Tambak Lorok for a relatively long period of time. The time for more than 21 years is more than enough time for a person to understand the physical, social, and economic conditions of Tambak Lorok. 


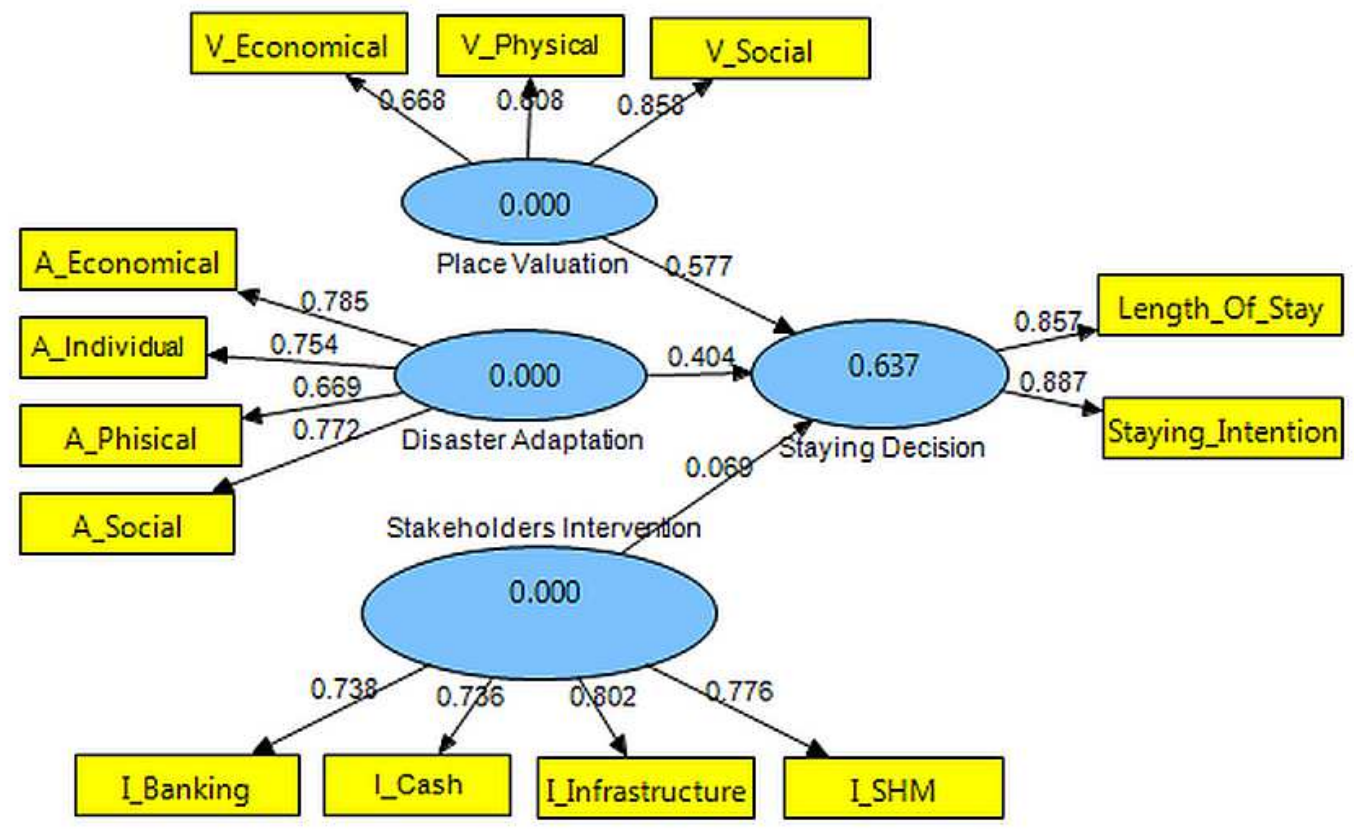

Fig. 2. Path coefficient of staying decision model.

The education level of respondents is dominated by elementary school $(40 \%)$. There are even respondents who have never attended school $(22.6 \%)$. There are only a few of the respondents who graduated from junior high school $(14.9 \%)$ and senior high school $(21.3 \%)$. While the respondents that graduated from university (D3 and S1) are a small part $(1.3 \%)$ of the respondent. In general, this indicates that the education level of respondents is low.

Most respondents $(41.3 \%)$ work as fishermen. The other respondent works as entrepreneurs $(26.8 \%)$, casual laborers $(16.2 \%)$, and contract employees $(14.5 \%)$ in factories in Tanjung Emas Port industrial area. The fewest respondents are those who work as permanent employees $(1.3 \%)$ who are teachers and employees of Semarang City Government.

In terms of income, most respondents (56\%) earn between IDR2,200,000 to IDR4,200,000. The city's minimum wage (UMK) of Semarang in 2016 is IDR2,125,000. Thus most of the respondents have income above the UMK. This shows that they have enough income to meet the minimum cost of living in Semarang city.

\subsubsection{Staying decision model}

The staying decision model and the path coefficients of each indicator in the model presented in Fig 2 . Furthermore, the results of the outer model and the inner model evaluation will be elaborated.

The results of the reflective model in the outer model evaluation show that there are two Indicators are not reliable. The Family's Future Valuation indicator (factor loading $=0.413$ ) is not a reference dimension of the Place Valuation construct and the Information Access (factor loadings $=0.477$ ) is not a reference dimension of the
Decision to Stay construct. Whilst the result of the formative model in the outer model evaluation show that the Mobility Experience indicator (cross loading= 0.514) is not valid in explaining the latent variable of Decision to Stay. Thus, there are 3 indicators that excluded from further calculations namely: Family`s Future Valuation, Information Access, and Mobility Experience.

Furthermore, Inner model evaluation consists of the coefficient of determination, effect size and relevance of prediction, and analysis of causal relationship in the structural model. PLS path modeling estimation for Staying Decision Model shows the coefficient of determination (R2) for endogenous latent variable Decision to Stay is 0.637. It means the exogenous latent variables (Place Valuation, Disaster Adaptation, and StakeHolder Intervention) have strong determinations and explain $63.7 \%$ variance of Staying Decision, while the remaining $36.3 \%$ is explained by other variables.

The effect size shows how good the model that viewed in effect size (f2) between constructs (exogenous latent variables to endogenous latent variables). The effect size of this model is presented in Table 3 below.

Table 3. The effect size among constructs

\begin{tabular}{|l|c|}
\hline \multicolumn{1}{|c|}{ Constructs } & $\mathbf{f}^{\mathbf{2}}$ \\
\hline Disaster Adaptation $\rightarrow$ Staying Decision & 0.362 \\
\hline Stake Holder Intervention $\rightarrow$ Staying Decision & 0.011 \\
\hline Place Valuation $\rightarrow$ Staying Decision & 0.867 \\
\hline
\end{tabular}

If the value is 0.02 means effect size is small, 0.15 means moderate, and 0.35 means substantial. Table 3 shows that the effect size of the Stake Holder Intervention construct (0.011) has a small effect on Decision to Stay, whereas the Place Valuation construct 
(0.867) and Disaster Adaptation construct (0.362) have a large effect on Decision to Stay.

While the prediction capability of a model measured by the value of Q2 (known as Stone-Geisser's value). Q2 also indicates the extent to which the model can be generalized for future research samples. The greater the value of Q2 indicates a better predictive level so as to have a greater degree of generalization. If the value is 0.02 means the predictive capability is small, 0.15 means moderate, and 0.35 means substantial. Table 4 shows the Q2 value of this model.

Table 4. The prediction capability of the model

\begin{tabular}{|l|c|c|c|}
\hline \multicolumn{1}{|c|}{ Constructs } & SSO & SSE & $\begin{array}{c}\mathbf{Q}^{\mathbf{2}} \\
(=\mathbf{1 - S S E} / \text { SSO })\end{array}$ \\
\hline Disaster Adaptation & 940,000 & 940,000 & \\
\hline $\begin{array}{l}\text { Stake Holder } \\
\text { Intervention }\end{array}$ & 940,000 & 940,000 & \\
\hline Place Valuation & 940,000 & 940,000 & \\
\hline Decision to Stay & 940,000 & 678,545 & 0.278 \\
\hline
\end{tabular}

Table 4 shows that this model has a $\mathrm{Q} 2=0.278$ so that the developed model has the considerable predictive capability. This means that the model developed in this study has a considerable degree of generalization when applied to samples in similar researches in the future.

The last inner model evaluation is to calculate the significance of the causal relationship between the latent variables. $T$ Statistical scores and coefficients in this structural model are shown in Table 5.

Table 5. The effect size between constructs

\begin{tabular}{|l|l|c|}
\hline \multicolumn{1}{|c|}{ Constructs } & T statistics & Coefficient \\
\hline $\begin{array}{l}\text { Disaster Adaptation } \rightarrow \\
\text { Staying Decision }\end{array}$ & $8.704^{* * *}$ & 0.404 \\
\hline $\begin{array}{l}\text { Stake Holder Intervention } \rightarrow \\
\text { Staying Decision }\end{array}$ & $1.662^{*}$ & 0.069 \\
\hline $\begin{array}{l}\text { Place Valuation } \rightarrow \\
\text { Staying Decision }\end{array}$ & $16.579 * * *$ & 0.577 \\
\hline
\end{tabular}

$* * *)$ significant at $\alpha 1 \%(\mathrm{t}$ value $\geq \pm 2.326)$

**) significant at $\alpha 5 \%$ (value $t \geq \pm 1.96$ )

*) significant at $\alpha 10 \%$ (t value \pm 1.645$)$

Table 5 shows that the causal relationship between Disaster Adaptation and Staying Decision is positive and significant at the level of $1 \%$ with a coefficient value of 0.404 . This means that the increase/decrease in Disaster Adaptation will corroborate Staying Decision statistically by 0.404 . Adaptation of good/bad to tidal disaster tends to influence Decision to stay/move from the disaster-prone area.

The causal relationship of Place Valuation and Staying Decision is positive and significant at the level of $1 \%$ with a significant value of 0.577 . This means that the increase/decrease in Place Valuation will corroborate Staying Decision statistically by 0.577 . Good/bad valuations of residential areas affect the decision to stay/move from disaster-prone areas.

The causal relationship between Stake Holder Intervention and Staying Decision is positive and significant at $10 \%$ level with a coefficient value of 0.069. Stake Holder Intervention increases (decreases) statistical Staying Decision by 0.069 . The causal relationship between Stake Holder Intervention and Staying Decision has the lowest significance and coefficient value compared to other causal relationships in this research model but remains significant. High/low level of Interventions by stakeholders influences the decision to stay/move from disaster-prone areas.

In sum, some important aspects obtained from the model are: (1). the determinant coefficient is strong (0.637); (2) the Place Valuation Construct contributes most (0.577) to the Staying Decision; (3) the Stakeholders Intervention Construct gives effect, but not significant to the Staying Decision; (4) Social Valuation gives the largest contribution in Place Valuation Construct (0.858); (5) Economic Adaptation contributes the most in Disaster Adaptation constructs (0.785); (6) the Infrastructure Intervention contributed the most in the Intervention Constructs (0.802).

\subsection{Discussion}

This model shows a statistically significant and positive correlation between Place Valuation and Staying Decision in disaster-prone areas. In addition, the model also reveals the extent to which the different dimensions of Place valuation contribute to the explanation of the decision to live in disaster-prone areas. The interesting thing is that among the other constructs, Place Valuation constructs are the most influencing dimensions of the Decision to Stay. This indicates that the decision to live in disaster-prone areas is largely determined by the valuation about the conditions of area of residence.

One important thing is that the social valuation has the strongest contribution to the Place Valuation construct. Thus, the valuation of the social conditions of residence is the most important factor affecting the decision to stay in the disaster-prone area. This proves that although migration can contribute significantly to the welfare and security of the household in the future, the migration required a significant social cost. In addition, migration will increase the risk to the nuclear family, also result in increased psychosocial stress and disconnection of social relationships with the migrant place of origin [16,17].

In relation to the social costs of migration, there is an interesting point from the results of this study, namely that Tambak Lorok residents have a low willingness to pay for social costs of migration. The reluctance to pay for the social cost of migration seems to have a strong influence on the decision to stay in disaster-prone areas. Tambak Lorok residence is lazing to move away from their current place because they do not want to lose the existing social environment. If they move to another place then they will lose their social environment that they value very high (most valuable). The survey results also show that the respondents considered that the social condition of Tambak Lorok is very good. Social interaction is very harmonious. Even some of the respondents stated that they did not find in other areas in 
Semarang City other than in Tambak Lorok that have a great social relation with the surrounding neighborhoods.

The economic valuations have an influence on Place Valuation. This is in line with Ravenstein's 7th Rule of Migration stating that economic motives are the main drivers of migration. The main cause of migration is to improve economic conditions [18]. In line with Ravenstein, the traditional way of explaining the flow of migration from one region to another is to view man as a homo economicus. Humans tend to compare the value of economic conditions in different regions and choose to live in areas that provide the highest economic benefits [19]. Massey's conclusion can be used to explain from the economic view why residents of Tambak Lorok choose to survive in the area despite experiencing physical environmental stresses in the form of periodic tidal floods that are getting worse over time.

The advantage of this model over other migration models (e.g. De Jong's model, 1981 [20]) is that this model not only describes the relationships among variables that affect the staying decision but also displays the quantitative value of the relationship. Therefore, this model can show which variables have the strongest influence on staying decision.

Finally, it can be delivered that model may also apply in many contexts of disaster-prone areas. Many places in Indonesia where the area is threatened by the disaster but the residents are reluctant to move. As in the slope of Mount Merapi, though threatened by the eruption of Merapi that takes place every $4-5$ years periodically the residents still do not move/migrate from the area. More than 90 percent of the population expressed pleasure to live on the slopes of Merapi and did not want to move [21]. As also happened to the people affected by Lapindo mudflow in Sidoarjo that occurred since 2006. The mudflow has not shown any signs of stopping, but the residents are still living around the disaster-prone areas [22].

\section{Conclusions}

Regarding the limited study of population immobility, especially immobility associated with climate changerelated disasters, what can this model explain? One interpretation is that the place valuation and disaster adaptation significantly influence the decision to stay, while stakeholder interventions are influential but not significant. This model shows that residents in the disaster-prone area with positive place valuation and good disaster adaptation tend to stay although threatening by the disaster.

We would like to acknowledge supports from Indonesia Endowment Fund for Education (LPDP) in making this research possible.

\section{References}

1. Bardsley, D. K. \& Hugo, G. J. Migration and climate change: examining thresholds of change to guide effective adaptation decision-making. Popul. Environ. 32, 238-262 (2010)

2. Zelinsky, W. The Hypothesis of the Mobility Transition. Geogr. Rev. 61, 219-249 (1971).

3. Mantra, I. B. Mobilitas penduduk sirkuler dari desa ke kota di Indonesia. (Pusat Penelitian Kependudukan, Universitas Gadjah Mada) (1989)

4. Sukamdi. Tipologi Migrasi: Suatu Alternatif Pengembangan Konsep. Populasi 2, 57-64 (1991)

5. Massey, D. S. et al. Theories of International Migration: A Review and Appraisal. Source Popul. Dev. Rev. 19, 431-466 (1993)

6. King, R. Theories and typologies of migration: An overview and a primer. Willy Brandt Series of Working Papers in International Migration and Ethnic Relations 3/12, (2012)

7. Lee, E. S. A Theory of Migration. Demography 3, 47-57 (1996)

8. Suhelmi, I. R., Fahrudin, A. \& Triwibowo, F. H. Potential Economic Losses Due to Tidal Inundation and Flood at Semarang City. Forum Geogr. 28, (2014)

9. Arief, L. N., Purnama, B. S. \& Aditya, T. Pemetaan Risiko Bencana Banjir Rob. 1st Conf. Geospatial Inf. Sci. Eng. 1-12 (2012)

10. Marfai, M. A. et al. The impact of tidal flooding on a coastal community in Semarang, Indonesia. Environmentalist 28, 237-248 (2008)

11. Marfai, M. A. \& King, L. Coastal flood management in Semarang, Indonesia. Environ. Geol. 55, 1507-1518 (2008)

12. Abidin, H. Z. et al. Studying Land Subsidence in Semarang (Indonesia) using Geodetic Methods. in FIG Congress. Facing the Challenges - Building the Capacity Sydney, Australia, 11-16 April 2010 1-15 (2010)

13. Sukamdi \& Mujahid, G. Internal Migration in Indonesia. (2015)

14. Ryan, T. P. Sample Size Determination and Power. (John Wiley \& Sons, 2013). doi:10.1002/9781118439241

15. Anderson, J. C. \& Gerbing, D. W. Structural Equation Modeling in Practice: A Review and Recommended Two-Step Approach. 103, 411423 (1988)

16. Kahn, K. et al. Health consequences of migration: Evidence from South Africa's rural northeast (Agincourt). in Conference on African Migration in Comparative Perspective 4-7 (2003)

17. Anna Lucia D'emilio et al. The Impact of International Migration: Children Left Behind in Selected Countries of Latin America and the Caribbean. (2007)

18. Ravenstein E. G. The Laws of Migration. J. Stat. Soc. London 48, 167-235 (1885) 
19. Massey, D. S. Social Structure, Household Strategies, and the Cumulative Causation of Migration. Popul. Index 56, 3-26 (1999)

20. De Jong, G. \& Gardner, R. Migration Decision Making. Multidisciplinary Approaches to Microlevel Studies in Developed and Developing Countries. (Pergamon Press, 1981)

21. Sontosudarmo, A. Persepsi Pengungsi Merapi dalam Transmigrasi. Maj. Geogr. Indones. 10, 37-57 (1996)

22. Sukamto. Mengenang Sepuluh Tahun Bencana Industri Lumpur Lapindo dan Tindakan Kolektif para Korban. J. Teor dan Pembelajaran IPS 1, 52-64 (2016) 